\title{
Lethal Cankers Caused by Phytophthora spp. in Almond Scions: Specific Etiology and Potential Inoculum Sources
}

\author{
G. T. Browne, USDA-ARS, Department of Plant Pathology, University of California, Davis 95616; M. A. Viveros, \\ University of California Cooperative Extension, 1031 South Mt. Vernon Ave., Bakersfield 93307
}

\begin{abstract}
Browne, G. T., and Viveros, M. A. 1999. Lethal cankers caused by Phytophthora spp. in almond scions: Specific etiology and potential inoculum sources. Plant Dis. 83:739-745.

Etiology of a new lethal canker syndrome of almond trees was investigated in the San Joaquin Valley of California. Phytophthora citricola was isolated most frequently from cankers limited to the aboveground scion portions of trees; whereas P. cactorum usually was isolated from cankers originating at or below the soil surface. Repeated observations and isolations indicated that some of the cankers associated with each species were perennial. In pathogenicity tests, isolates of $P$. cactorum and $P$. citricola caused bark cankers in excised segments of almond shoots and branches, as well as root and crown rot on potted almond seedlings. Only P. citricola caused significant disease in root and crown tissues of peach seedlings. When pear fruits and almond seedlings were used as bait, $P$. cactorum and $P$. citricola were isolated from orchard soil, debris collected in natural depressions where scaffold branches and the tree trunk joined at a common point, and debris deposited on tree surfaces during nut harvest. Control strategies for Phytophthora diseases of almond should consider aboveground as well as belowground modes of attack by $P$. citricola and P. cactorum. Debris infested with these pathogens and deposited on trees during harvest may play a role in the disease epidemiology.
\end{abstract}

Additional keywords: Prunus dulcis

Phytophthora spp. are among the most serious soilborne pathogens of cultivated Prunus spp. In almond (Prunus dulcis (Mill.) D. Webb), more than 10 Phytophthora spp. are known to cause root and crown rots that result in tree decline and death $(6,12,19,25,32)$. Previous research on Phytophthora diseases of temperate orchard crops has focused on the root and crown rots and has determined that these diseases are favored by prolonged, repeated periods of water saturation in soil $(3,21,33)$. Key approaches used to control Phytophthora root and crown rots include nursery and orchard sanitation measures, careful soil water management, and selection of rootstocks with resistance to the pathogens $(4,22,26)$.

In addition to their role as root system pathogens, several Phytophthora spp. can cause direct aboveground damage. For example, Phytophthora cactorum (Lebert \& Cohn) J. Schröt. incites fruit rots of pome fruits and strawberry $(7,11,20)$, shuck and kernel rot of pecan (27), as well

Corresponding author: G. T. Browne

E-mail: gtbrowne@ucdavis.edu

Accepted for publication 1 April 1999.

Publication no. D-1999-0602-01R

This article is in the public domain and not copyrightable. It may be freely reprinted with customary crediting of the source. The American Phytopathological Society, 1999. as crown rot on many hosts (11). Similarly, Phytophthora syringae (Kleb.) Kleb. causes pruning wound cankers in almond $(2,9)$, fruit rots of apple and citrus $(7,11,29)$, leaf and shoot infections of lilac, in addition to crown and collar infections on many hosts (11). P. citricola Sawada causes both aboveground blight and belowground crown and root rot on a variety of host plants (11). Subterranean infections by Phytophthora spp. can extend up the trunk and scaffold branches $(15,17,19,24,25)$.

Several mechanisms have been demonstrated or hypothesized for spread of Phytophthora spp. from soil to aerial sites of host infection, including wind and rain splashing, and transport by insects, snails, and rodents $(10,11)$. Phytophthora spp. also have been associated with scion cankers of deciduous fruit and nut trees following orchard inundation with flood water or prolonged sprinkler irrigation with Phytophthora-infested surface water (S. M. Mircetich and G. T. Browne, unpublished).

In recent years, California almond trees infected by Phytophthora spp. have exhibited diverse disease symptoms (6). Trees in some orchards have sustained Phytophthora root and crown rots or pruning wound cankers that have been described previously $(2,9,19,25)$. The orchards with high incidences of crown rot caused by $P$. megasperma Drechs. are commonly less than 5 years old and situated on poorly drained soils (6). Pruning wound canker caused by $P$. syringae has occurred spo- radically throughout the San Joaquin and Sacramento valleys, but the cankers cease development with the onset of warm weather in late spring, usually before serious tree damage occurs $(2,9)$. In some cases, atypical Phytophthora cankers were observed leading to a lethal aboveground syndrome. This disease is typified by rapidly expanding cankers that exhibit a gummosis and eventually girdle affected tree trunks and scaffold branches (6). Isolations from the diseased trees have yielded either $P$. cactorum or $P$. citricola. Incidences of this disease have been observed mainly in the arid southern portion of the San Joaquin Valley, and the infected trees have been of prime bearing age ( $>8$ years old). Although poor surface water penetration can be a problem in the region, the affected orchards typically were situated on class-one soils with good internal water drainage properties. Many of the cankers had expanded sufficiently to prevent determination of whether the origin of infection was above or below ground. In contrast to pruning wound canker caused by $P$. syringae, the cankers associated with $P$. cactorum or $P$. citricola have caused up to $5 \%$ or more tree mortality (6). We refer to the latter canker disease as "lethal Phytophthora canker" (LPC) to distinguish it from the pruning wound canker disease caused by $P$. syringae.

This study was undertaken to determine the etiology of LPC of almond, sites of canker initiation, and sources of inoculum. This basic information is critical to development of appropriate control strategies for the disease. A preliminary account of a portion of this work was reported previously (6).

\section{MATERIALS AND METHODS}

Orchard surveys and sample collection. In the San Joaquin Valley, seven almond orchards in which trees were declining and dying from rapidly expanding cankers with profuse gumming were surveyed from 1994 to 1997. Bark samples were collected from the canker margins and kept moist and cool until diagnostic lab isolations were performed. Dry, inactive cankers and those that were associated with mechanical harvester wounds and exhibited symptoms characteristic of infection by Ceratocystis fimbriata $(8,26,28)$ were avoided.

Isolation and identification of Phytophthora spp. Pieces of the necrotic bark 
samples were cultured in a modified PARP medium (18) using methods that have been described previously (4). Specifically, the modified medium consisted of corn meal agar (CMA, 17 g/liter, Difco Laboratories, Detroit, MI) amended with pimaricin (10 $\mathrm{mg} / \mathrm{liter}$ ), ampicillin (250 mg/liter), rifampicin $(10 \mathrm{mg} / \mathrm{liter})$, and pentachloronitrobenzene $(25 \mathrm{mg} / \mathrm{liter})$. Isolates of Phytophthora spp. were subcultured and identified using techniques and media previously described (4) along with published keys $(11,30)$.

Pathogenicity tests. Representative isolates of Phytophthora spp. from lethal cankers were tested for pathogenicity in excised almond shoots, excised almond branches, and potted almond and peach seedlings. Isolates of $P$. megasperma from almond root crowns were included for comparison. One-year-old shoots (4 to 5 $\mathrm{mm}$ diameter) were excised from actively growing almond trees of cv. Nonpareil, trimmed to remove leaves, lateral shoots, and spurs, and cut to $20-\mathrm{cm}$ length. The shoots were inoculated with mycelial disks of V8 agar as described previously (5); controls were inoculated with sterile V8 juice agar disks. The inoculated shoots were supported on screens above a free water surface in plastic chambers to maintain ambient $100 \%$ relative humidity; temperature was 20 to $24^{\circ} \mathrm{C}$. The experiment used a randomized complete block design in which three humid chambers each contained one replicate block of Phytophthora-inoculated and control shoots. Each block included two sets (subsamples) of inoculated and control shoots.

In a second experiment, isolates were tested for pathogenicity in excised branch segments of almond cv. Nonpareil. Two isolates of $P$. megasperma from diseased almond root crowns were included for comparison with LPC isolates of $P$. cactorum and $P$. citricola. The branch segments were 2 to $5 \mathrm{~cm}$ in diameter and 15 $\mathrm{cm}$ in length. Inoculations were conducted as for the 1-year-old shoots, except the branches were incubated for 7 days and five replicate humid chambers were used, each containing only one set (a block) of branch segments.

In a third experiment, isolates were tested on seedlings of almond cv. Nonpareil and peach (Prunus persica (L.) Batsch) cv. Nemaguard in a greenhouse. In preparation, seeds were stratified in peat moss for 3 months (14), sprouted, and planted in 0.2 -liter pots of UC mix soil (1). Inocula of the Phytophthora spp. were grown on V8 juice vermiculite medium in canning jars and prepared for inoculations as described previously (3). The almond and peach seedlings were transplanted individually into 1-liter pots containing either noninfested UC mix (control) or artificially infested UC mix. The soil was artificially infested with a Phytophthora isolate by mixing thoroughly with $35 \mathrm{ml}$ of the V8 vermiculite inoculum per liter of UC mix, while the noninfested control soil received sterile V8 vermiculite medium at the same rate. Each isolate of Phytophthora and the control was imposed on five replicate almond and five replicate peach seedlings. The plants were fertilized at weekly intervals with Grow More fertilizer (11-7-26, Gardena, CA).

Starting 1 week after transplanting, all plants were subjected to 48 -h periods of flooding once every 2 weeks. The pots were placed in bowls and flooded to maintain a water surface at 0.5 to $1 \mathrm{~cm}$ above the soil surface. Between periods of flooding, the plants were watered daily and the soil drained freely. Three months after transplanting, the root systems were washed free from soil and examined. The percentage of each seedling's roots that appeared rotted (reddish brown in cortex and stele) was estimated visually. In addition, the percentage of crown length rotted was measured.

At the conclusion of each pathogenicity test, isolations were conducted from symptomatic and asymptomatic (control) plant parts to confirm associations between Phytophthora spp. and symptoms. For inoculated shoots and branches, bark samples were cultured in PARP medium. For plants grown in soil, root and crown tissues were cultured into the medium.

Sites of canker initiation on trees. Four of seven orchards described above (orchard surveys) were surveyed during March 1997 to June 1998 to locate all Phytophthora cankers in early stages of development and to determine sites of canker origin. In orchards 1, 2, 3, and 4, the numbers of trees surveyed were 1,640, 1,790, 490, and 450, respectively. Each canker exhibiting gummosis and evidence of recent expansion was exposed by removing portions of bark. The cankers were diagrammed schematically to denote locations of active and inactive margins and portions of the canker where the necrotic bark was dry and undergoing secondary decay. In addition, the proximity of the canker features was noted in relation to the tree trunk, scaffold crotch pockets (the natural depression formed where scaffold branches join the trunk at a common point), scaffold branches, and pruning wounds.

Cankers were categorized as having either an aboveground or a belowground origin on trees. In the former category, bark and cambium necrosis was limited to aboveground tree parts. Where possible, aboveground classifications noted specific sites of canker origin, i.e., on the trunk, in the scaffold crotch pocket, or on a scaffold branch. Furthermore, it was indicated whether cankers were associated with pruning wounds. Cankers of belowground origin exhibited an active zonate margin advancing vertically upward on the tree trunk, and necrosis was continuous be- tween the soil surface and the upper canker margin. Drying and cracking of necrotic bark was often apparent at the trunk base where it joined the soil. Cankers were excluded from analysis if they were too extensive to allow classification. Samples were collected from each classified canker, labeled to indicate exact location, and subjected to diagnostic isolation procedures (described above).

Potential sources of inoculum. In orchards affected by LPC, baiting and assay procedures were used to assess potential sources of inoculum for the disease. As one approach, pear baiting procedures were used in situ for detection of Phytophthora spp. in scaffold crotch pockets at three orchards. Healthy pockets were selected that were sufficiently deep to allow partial submersion of pears when water was added. One pear was placed in each baited pocket. Tap water was supplied to the pockets by drip emitters connected to portable covered reservoirs. The water was supplied at 0.7 liter/h during two 10-h periods that were separated by a $10-\mathrm{h}$ period without added water. Control baiting stations consisted of pears partially submerged in bowls of tap water and placed in scaffold crotch pockets. At least five baited pockets and five controls were used per orchard. About $40 \mathrm{~h}$ after placement, all pears were collected, rinsed, and incubated at room temperature for 1 week to allow development of lesions. Additional pear baiting was conducted with soil samples from LPC orchards using previously described procedures (4).

In another approach to detecting inoculum, recently sprouted volunteer almond seedlings were collected from debris in noncankered scaffold crotch pockets and from soil under LPC-affected trees. The seedlings, which were 10 to $15 \mathrm{~cm}$ in length from shoot tip to main root tip, grew from nuts remaining after the previous harvest and had sprouted within a few months before collection. Some of the seedlings were affected by stem cankers or root rot. Root and stem tissues of the seedlings were inspected for symptoms of infection by Phytophthora, and symptomatic tissues were cultured in PARP selective medium.

To assess potential deposition of Phytophthora inoculum on trees during harvest, plastic tarps (3-mil thickness, $1.5 \times$ $1.5 \mathrm{~m}$ area) were fastened onto scaffold branches in tree centers to form vaseshaped "collection traps." The traps were used in two orchards (46 to 47 traps per orchard) and located in healthy trees within orchard areas that had relatively high incidence of LPC. Trap placement coincided with nut sweeping and pickup operations, which blow large amounts of dust and debris into the air and onto trees. Eight to 10 days after trap placement, the debris samples were collected in paper sacks and stored at room temperature. The contents 
were dry-sieved through a 2-mm-opening screen and weighed. The screen was sterilized between samples. Sieved contents ( 0.2 to $26.3 \mathrm{~g}$, mean $6.1 \mathrm{~g}$ ) were mixed with 0.1 to 0.2 liter of sterilized UC mix or a mineral potting mix (Yolo loam:sand:vermiculite:perlite, 2:2:1:1, $\mathrm{vol} / \mathrm{vol} / \mathrm{vol} / \mathrm{vol}$ ), and placed in separate 0.2 -liter pots. Controls consisted of only the potting soils in 0.2 -liter pots. The pots with and without debris were incubated in a growth chamber that maintained $18^{\circ} \mathrm{C}, 80 \%$ relative humidity, and a 16-h photoperiod.

In one attempt to detect Phytophthora spp. in the harvest debris samples, seeds of almond cv. Nonpareil were stratified for 6 to 10 weeks (14) and planted singly in test pots. Seedlings were fertilized at biweekly intervals with Miracle Gro fertilizer (1530-15, Port Washington, NY). Three weeks after planting, the seedlings were flooded for 24 to $48 \mathrm{~h}$ once every week for 8 weeks. At 13 weeks after planting, all seedlings were removed and assayed for infection by a Phytophthora sp. Ten root pieces per plant were cultured in PARP medium.

In a second attempt at detecting Phytophthora spp., the potted soils were transferred to 1-liter beakers and baited with pears. For each baiting episode, one pear was placed to a beaker, which was flooded with sterile deionized water to partially submerge the fruit for $48 \mathrm{~h}$. After flooding, the pears were removed, rinsed, and incubated for 1 week. During the incubation, portions of lesions that developed were cultured on PARP medium. Some beakers were rebaited with pears up to two more times.

\section{RESULTS}

Association of Phytophthora spp. with cankers. Among the seven orchards surveyed, Phytophthora spp. were isolated from 109 of 237 cankers sampled from 1994 to 1997 (Table 1). P. cactorum and $P$. citricola were isolated from cankers that continued expansion during late spring and early summer. The damage was typically extensive, finally resulting in tree death. In contrast, $P$. syringae was isolated from cankers that ceased expansion by late spring without serious tree damage. All three species were associated with canker development in flood-irrigated as well as in microsprinkler-irrigated orchards (Table 1). However, P. citricola predominately was isolated from trees in microsprinklerirrigated orchards, and $P$. cactorum predominately was isolated from trees in flood-irrigated orchards (Table 1). LPC occurred on all cultivars surveyed, including Carmel, Fritz, Nonpareil, Price, and Sonora. Furthermore, trees on peach rootstock as well as trees on almond $\times$ peach hybrid rootstock were affected (Table 1).

Some cankers caused by $P$. cactorum and $P$. citricola were perennial. For example, among eight cankers diagnosed and cultured in March 1997, six yielded $P$. citricola; when the same eight cankers were rechecked in June 1998, P. citricola was reisolated from two of them. Furthermore, among other trees, $P$. citricola and $P$. cactorum were isolated singly from expansive ( $1 \mathrm{~m}$ or more in vertical length) cankers during the months of October and November, which suggested that the pathogens had oversummered there. Additional isolations of both species from ex- pansive cankers during January to March suggested that the pathogens successfully overwintered as well.

Average upward canker extension was determined for five cankers caused by $P$. citricola. From March 1997 to June 1998, canker margins expanded by an average of $66 \mathrm{~cm}$ (range 27 to $121 \mathrm{~cm}$, data not shown). However, cankers caused by $P$. cactorum and $P$. citricola appeared relatively inactive in July, August, and Sep-

Table 1. Some features of almond orchards affected by lethal Phytophthora cankers and results of isolation attempts during 1994 to 1997

\begin{tabular}{|c|c|c|c|c|c|}
\hline $\begin{array}{l}\text { Orchard } \\
\text { no. }\end{array}$ & $\begin{array}{l}\text { Method of } \\
\text { irrigation }\end{array}$ & $\begin{array}{c}\text { Water } \\
\text { deposition }\end{array}$ & Rootstock type & $\begin{array}{c}\text { Cankers } \\
\text { yielding } \\
\text { Phytophthora }\end{array}$ & $\begin{array}{l}\text { Species isolated } \\
\text { (no. of isolates) }\end{array}$ \\
\hline 1 & Microsprinkler & + & Peach & $34 / 52$ & $\begin{array}{l}\text { P. cactorum }(5)^{\mathrm{w}} \\
\text { P. citricola }(29)^{\mathrm{w}}\end{array}$ \\
\hline 2 & Microsprinkler & - & Almond $\times$ peach & $36 / 72$ & P. citricola $\mathrm{w}$ \\
\hline 3 & Flood & - & Peach & $13 / 37$ & $\begin{array}{l}\text { P. cactorum }(12)^{\mathrm{w}} \\
\text { P. citricola }(1)^{\mathrm{w}}\end{array}$ \\
\hline 4 & Microsprinkler & $+/-x$ & Almond $\times$ peach & $5 / 40$ & $\begin{array}{l}\text { P. citricola }(2)^{\mathrm{w}} \\
\text { P. syringae }(2)^{\mathrm{y}} \\
\text { Phytophthora } \mathrm{sp} .(1)^{\mathrm{w}, \mathrm{z}}\end{array}$ \\
\hline 5 & Flood & - & Peach & $6 / 7$ & $\begin{array}{l}\text { P. cactorum }(3)^{\mathrm{w}} \\
\text { Phytophthora } \mathrm{sp} .(3)^{\mathrm{w}, \mathrm{z}}\end{array}$ \\
\hline 6 & Flood & - & Peach & $9 / 19$ & $\begin{array}{l}\text { P. cactorum }(7)^{\mathrm{w}} \\
\text { P. syringae }(2)^{\mathrm{y}}\end{array}$ \\
\hline 7 & Flood & - & Almond $\times$ peach & $6 / 10$ & P. cactorum $^{\mathrm{w}}$ \\
\hline
\end{tabular}

${ }^{\mathrm{v}}$ Cankers yielding Phytophthora sp./total cankers. Bark samples were collected from margins of cankers and cultured in PARP selective medium.

w Isolates from "lethal-type" cankers that typically expanded to cause decline and death of trees.

${ }^{x}$ Some tree trunks were wetted.

${ }^{y}$ Isolates typically from pruning wound cankers that ceased development by late spring without serious tree damage.

${ }^{\mathrm{z}}$ Isolates lost before complete identification.

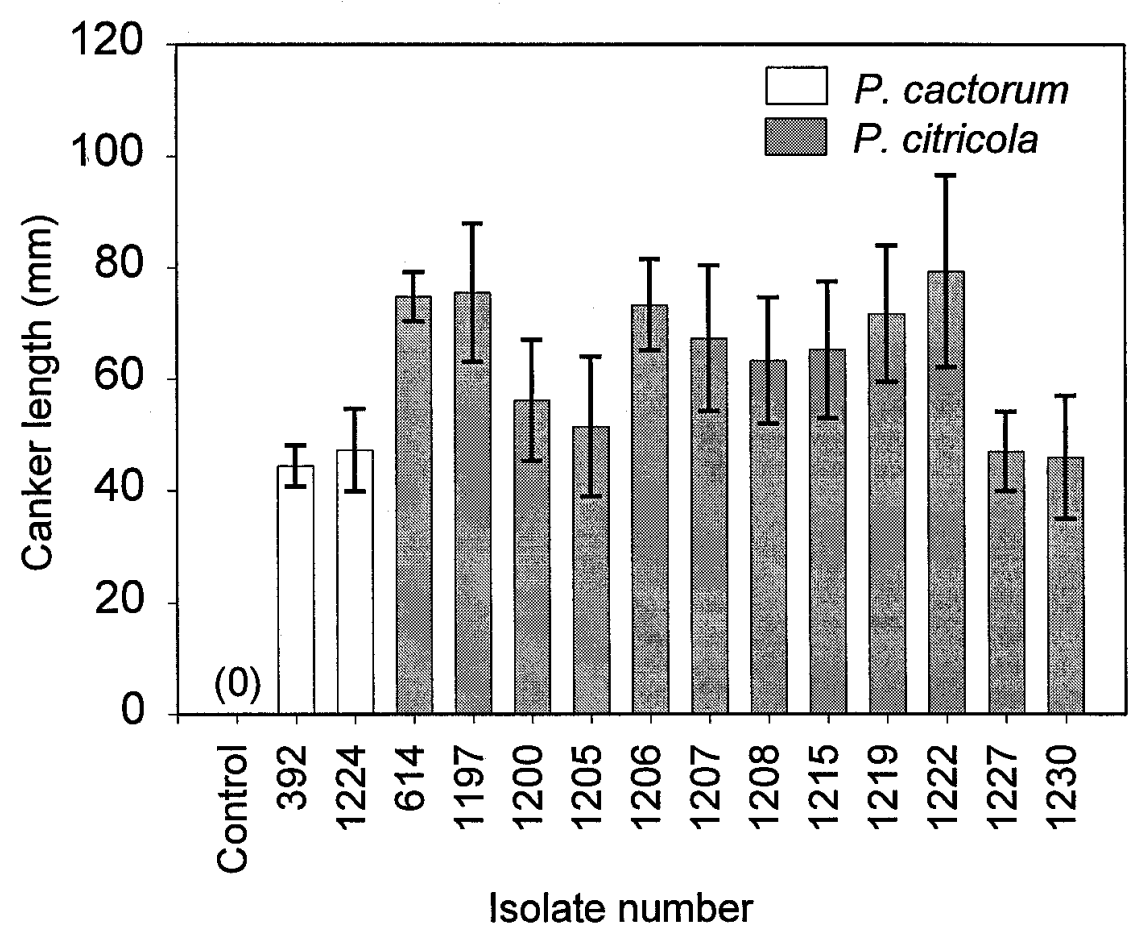

Fig. 1. Pathogenicity of Phytophthora cactorum and P. citricola in excised 1-year-old almond shoots (4 mm diameter $\times 20 \mathrm{~cm}$ long). Isolates were obtained from lethal Phytophthora cankers on almond trees. Error bars indicate standard error of the means $(n=3$, with two subsample shoots per replicate). 
tember, as evidenced by less pronounced gummosis, relatively little advancement of canker margins, and difficulty in isolation of the pathogens.

Pathogenicity tests. All isolates of $P$. cactorum and $P$. citricola caused cankers in 1-year-old almond shoots within 5 days after inoculation, and the noninoculated control shoots remained symptomless (Fig. 1). Similarly, in the excised branch segments, all isolates of $P$. cactorum and $P$. citricola proved pathogenic (Fig. 2), including isolate 1224 of $P$. cactorum and 1215 of $P$. citricola, which were tested in excised shoots (Fig. 1). On average, can- kers caused by $P$. megasperma were less than half the length of those caused by $P$. cactorum and P. citricola (Fig. 2).

With potted almond seedlings, no disease occurred in the controls, but all tested isolates of $P$. cactorum, $P$. citricola, and $P$. megasperma caused root and crown rot (Table 2). With Nemaguard peach seedlings, the isolates of $P$. citricola and $P$. megasperma caused mild to severe root and crown rot compared with the control, but the isolates of $P$. cactorum caused negligible disease (Table 2).

At the conclusions of pathogenicity tests, $P$. cactorum, $P$. citricola, and $P$.

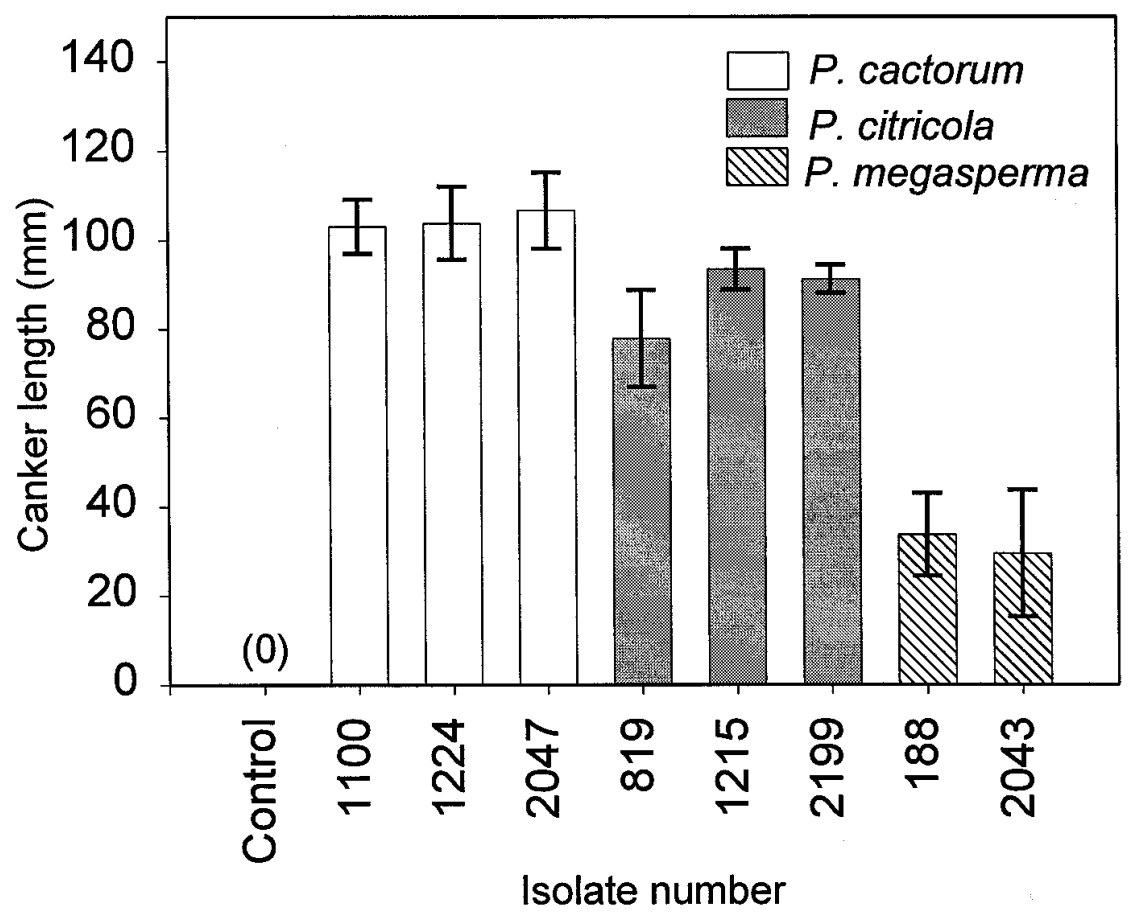

Fig. 2. Pathogenicity of almond canker isolates of Phytophthora cactorum and P. citricola and root crown isolates of $P$. megasperma in excised almond branch segments ( 2 to $5 \mathrm{~cm}$ diameter $\times 15 \mathrm{~cm}$ long). Error bars indicate standard error of the means $(n=5)$.

Table 2. Pathogenicity and relative virulence of Phytophthora cactorum and P. citricola isolates from lethal Phytophthora cankers and of $P$. megasperma isolates from root crowns ${ }^{\mathrm{z}}$

\begin{tabular}{lcccccc}
\hline & & \multicolumn{3}{c}{$\begin{array}{c}\text { Percent root crown length } \\
\text { rotted }\end{array}$} & & \multicolumn{2}{c}{ Percent roots rotted } \\
\cline { 3 - 4 } \cline { 6 - 7 } Phytophthora species & Isolate no. & Almond & $\begin{array}{c}\text { Nemaguard } \\
\text { peach }\end{array}$ & & Almond & $\begin{array}{c}\text { Nemaguard } \\
\text { peach }\end{array}$ \\
\hline Control (noninoculated) & $\ldots$ & $0 \mathrm{~d}$ & $0 \mathrm{c}$ & & $1 \mathrm{c}$ & $3 \mathrm{c}$ \\
P. cactorum & 1040 & $9 \mathrm{~cd}$ & $1 \mathrm{c}$ & & $21 \mathrm{c}$ & $3 \mathrm{c}$ \\
& 1098 & $50 \mathrm{~b}$ & $6 \mathrm{bc}$ & & $67 \mathrm{~b}$ & $11 \mathrm{c}$ \\
& 1100 & $70 \mathrm{ab}$ & $4 \mathrm{bc}$ & & $82 \mathrm{ab}$ & $7 \mathrm{c}$ \\
& 1217 & $68 \mathrm{ab}$ & $14 \mathrm{abc}$ & & $77 \mathrm{ab}$ & $14 \mathrm{c}$ \\
& 819 & $100 \mathrm{a}$ & $41 \mathrm{a}$ & & $100 \mathrm{a}$ & $55 \mathrm{~b}$ \\
& 1215 & $80 \mathrm{ab}$ & $31 \mathrm{ab}$ & & $100 \mathrm{a}$ & $24 \mathrm{c}$ \\
& $188 \mathrm{a}$ & $42 \mathrm{bc}$ & $39 \mathrm{a}$ & & $85 \mathrm{ab}$ & $72 \mathrm{ab}$ \\
& 1302 & $60 \mathrm{ab}$ & $31 \mathrm{ab}$ & & $98 \mathrm{a}$ & $83 \mathrm{a}$ \\
\hline
\end{tabular}

${ }^{\mathrm{z}}$ At 4 months of age, potted peach and almond seedlings were transplanted into noninfested soil (controls) or soil artificially infested with an isolate of a Phytophthora sp. Starting 1 week after transplanting, the seedlings were subjected to biweekly 48 -h periods of flooding. Three months after transplanting, the roots were washed free from soil and assessed for incidence and severity of disease. There were five replicate plants per treatment. Means within a column and without letters in common are significantly different according to DMRT, $P=0.05$. megasperma were consistently reisolated from the appropriate shoots and seedlings. Isolations from the noninoculated plants were negative for Phytophthora spp.

Sites of tree infection. Data presented on sites of tree infection (Table 3) are limited to cankers that yielded a Phytophthora sp. Among cankers with Phytophthora at orchards 1, 2, and 4, most infections (73 to $100 \%$ ) were limited to aboveground tree parts (Table 3). However, $86 \%$ of the cankers at orchard 3 originated from infection belowground (Table 3). The cankers in orchards 1,2, and 3 were caused by either $P$. cactorum or $P$. citricola, and all appeared perennial in nature. In contrast, the two cankers at orchard 4 were caused by $P$. syringae, and both ceased activity by late spring.

$P$. citricola usually was isolated from the aboveground infections, while $P$. cactorum was the most common species from belowground infections (Table 3). A chisquare test (FREQ procedure, SAS; SAS Institute, Cary, NC) performed on combined data from orchards 1 and 3 indicated that the incidence ratio of aboveground to belowground infections was significantly greater for $P$. citricola than for $P$. cactorum $(P=0.001)$.

The tendency for $P$. cactorum to infect belowground was not universal. In orchard 7 (Table 1), P. cactorum had initiated LPC mainly in scaffold crotch depressions, and the cankers usually had not reached the soil surface (data not shown).

There was no consistent association between cankers caused by $P$. cactorum or $P$. citricola and pruning wounds (Table 3 ). Only about one quarter of the aboveground cankers included a pruning wound, and in many of these cases, the pruning wound did not seem to be the site of infection.

Potential sources of inoculum. $P$. $c a c$ torum and $P$. citricola were detected in soil, debris in scaffold crotch pockets, and debris deposited in collection traps during harvest (Tables 4 and 5). On several occasions, $P$. cactorum and $P$. citricola were isolated from volunteer almond seedlings that were gathered from beneath orchard trees or from debris in scaffold crotch pockets (Table 4). In contrast, the pear baiting assays failed to isolate either pathogen from the pockets (and accompanying controls), although $P$. citricola was isolated from pears used in flooded orchard soil (Table 4).

In the potted soils with harvest debris samples added, many assay seedlings died soon after planting; whereas control seedlings produced healthy growth. After fertilization and flooding, most plants, including controls, exhibited a phytotoxic response (leaf scorching, wilting, chlorosis). Subsequently, isolations from 26 seedlings from orchard 1 samples and 21 from orchard 2 samples yielded one isolate of $P$. parasitica and one of $P$. megasperma, respectively. The isolations were compli- 
cated by almost universal presence of rapidly growing Pythium sp. colonies. Companion isolations from 36 control seedlings yielded only a few isolates of Pythium sp. and Mortierella sp. and no isolates of Phytophthora. In contrast to seedling assays, the subsequent pear-baiting assays isolated $P$. cactorum, $P$. citricola, $P$. parasitica, $P$. syringae, and an unidentified Phytophthora sp. with nonpapillate sporangia (Table 5). $P$. cactorum was detected only from orchard 2; whereas $P$. citricola was detected from both orchards (Table 5).

\section{DISCUSSION}

$P$. cactorum and $P$. citricola are important causes of LPC in California almond trees, as indicated by results of the orchard surveys, canker isolations, and pathogenicity tests. Both species initiated scion can- kers from belowground as well as aboveground sites of infection, although $P$. citricola consistently tended to attack aboveground and $P$. cactorum usually attacked belowground. It is the aboveground infections that differ from previously described almond diseases. Scion cankers resulting from belowground infection by Phytophthora spp. are technically expansions of crown rot. Several investigators have reported Phytophthora crown and root rots of almond with occasional involvement of cankers that extend up the trunk from belowground infection $(6,19,25,32)$. Similarly, Phytophthora-induced stem canker of peach has occurred in connection with Phytophthora crown and root rot $(15,24)$. To our knowledge, this is the first report to document LPC caused by $P$. cactorum and $P$. citricola in almond.

Table 3. Categorization of the cankers that yielded a Phytophthora sp.

\begin{tabular}{|c|c|c|c|c|c|}
\hline \multirow[b]{2}{*}{$\begin{array}{l}\text { Orchard } \\
\text { no. }\end{array}$} & \multirow[b]{2}{*}{$\begin{array}{l}\text { Category of } \\
\text { infection site }\end{array}$} & \multirow[b]{2}{*}{ Percent } & \multicolumn{2}{|c|}{ Cankers } & \multirow[b]{2}{*}{$\begin{array}{l}\text { Phytophthora sp. } \\
\text { isolated (no. cankers) }\end{array}$} \\
\hline & & & Total & $\begin{array}{l}\text { With pruning } \\
\text { wounds }\end{array}$ & \\
\hline \multirow[t]{5}{*}{1} & Belowground ${ }^{\mathrm{x}}$ & 27 & 7 & $\ldots$ & $\begin{array}{l}\text { P. cactorum }(5), \\
\text { P. citricola }(2)\end{array}$ \\
\hline & Abovegroundy & 73 & 19 & 5 & P. citricola \\
\hline & On tree trunk & 8 & 2 & 0 & P. citricola \\
\hline & In scaffold crotch ${ }^{\mathrm{z}}$ & 19 & 5 & 1 & P. citricola \\
\hline & On scaffold & 0 & 0 & 0 & $\ldots$ \\
\hline \multirow[t]{5}{*}{2} & Belowground & 5 & 2 & $\ldots$ & P. citricola \\
\hline & Aboveground & 95 & 35 & 8 & P. citricola \\
\hline & On tree trunk & 32 & 12 & 0 & P. citricola \\
\hline & In scaffold crotch & 24 & 9 & 2 & P. citricola \\
\hline & On scaffold & 13 & 5 & 1 & P. citricola \\
\hline \multirow[t]{5}{*}{3} & Belowground & 86 & 6 & $\ldots$ & P. cactorum \\
\hline & Aboveground & 14 & 1 & 0 & P. citricola \\
\hline & On tree trunk & 14 & 1 & 0 & P. citricola \\
\hline & In scaffold crotch & 0 & 0 & 0 & $\ldots$ \\
\hline & On scaffold & 0 & 0 & 0 & $\ldots$ \\
\hline \multirow[t]{5}{*}{4} & Belowground & 0 & 0 & $\ldots$ & $\ldots$ \\
\hline & Aboveground & 100 & 2 & 1 & P. syringae \\
\hline & On tree trunk & 50 & 1 & 0 & P. syringae \\
\hline & In scaffold crotch & 0 & 0 & 0 & $\ldots$ \\
\hline & On scaffold & 50 & 1 & 1 & P. syringae \\
\hline
\end{tabular}

${ }^{x}$ Cankers originating at or below the soil surface and extending vertically up the tree trunk.

y Aboveground cankers not connected with the soil. When possible, cankers were categorized further as originating on a tree trunk, scaffold crotch, or scaffold branch.

${ }^{\mathrm{z}}$ A natural depression that can form where the tree trunk and scaffold branches join.

The fact that slightly less than half of the sampled cankers yielded a Phytophthora sp. (Table 1) probably resulted in part from limitations of the isolation method. It is also possible that some cankers had causes other than Phytophthora. The conclusions of this paper are based on the cankers of confirmed infection status. Phytophthora spp. can be difficult to isolate, even with semiselective media (11). In general, detection of $P$. cactorum and $P$. citricola from scion cankers was most successful in the early spring and late fall and least successful during summer and early fall.

Several important features distinguished LPC from previously described pruning wound cankers caused by $P$. syringae, Ceratocystis (mallet wound) cankers caused by $C$. fimbriata, and crown rots caused by Phytophthora spp. For example, in contrast to cankers caused by $P$. syringae, LPC exhibited no consistent association with pruning wounds; rather, LPC usually occurred on trunks, scaffold crotch pockets, and scaffold branches without involvement of pruning wounds (Table 3). Additionally, LPC cankers often killed trees; whereas pruning wound cankers are typically annual and nonlethal. Ceratocystis cankers are initiated at wound sites, expand most rapidly during summer months, and exhibit pronounced staining in the xylem under and near cankers $(8,26,28)$; whereas LPC cankers were relatively inactive in middle and late summer and did not exhibit staining deep in the xylem.

The fact that almond tree death can result from either aboveground or belowground attack by $P$. cactorum or $P$. citricola complicates control strategies for Phytophthora-induced diseases of the crop. Careful soil water management and choice of a relatively resistant rootstock will aid control of subterranean infections by Phytophthora spp. (22,23), but these approaches alone may not control LPC.

Specific times of year when $P$. cactorum and $P$. citricola infect almond trees remain largely unknown, although some generali-

Table 4. Detection of Phytophthora spp. in potential reservoirs of inoculum in orchards affected by lethal Phytophthora canker

\begin{tabular}{|c|c|c|c|c|c|c|c|c|}
\hline \multirow[b]{2}{*}{$\begin{array}{l}\text { Orchard } \\
\text { no. }\end{array}$} & \multirow[b]{2}{*}{ Sampling site } & \multirow[b]{2}{*}{$\begin{array}{l}\text { Sampling } \\
\text { month }\end{array}$} & \multirow[b]{2}{*}{ Isolation procedure } & \multirow[b]{2}{*}{$\begin{array}{c}\text { Total no. tree or } \\
\text { soil sites sampled }\end{array}$} & \multicolumn{4}{|c|}{ No. yielding Phytophthora sp. } \\
\hline & & & & & $\begin{array}{c}P . \\
\text { cactorum }\end{array}$ & $\begin{array}{c}P . \\
\text { citricola }\end{array}$ & $\begin{array}{c}P . \\
\text { syringae }\end{array}$ & $\begin{array}{l}\text { Phytoph- } \\
\text { thora sp. }\end{array}$ \\
\hline \multirow[t]{2}{*}{1} & Scaffold crotch pocket ${ }^{x}$ & Nov & in situ peary & 5 & 0 & 0 & 0 & 0 \\
\hline & Orchard soil & Apr & Pear & 5 & 0 & 1 & 0 & 0 \\
\hline \multirow[t]{4}{*}{2} & Scaffold crotch pocket & Nov & in situ pear & 13 & 0 & 0 & 0 & 0 \\
\hline & Scaffold crotch pocket & Mar & Almond seedlings ${ }^{z}$ & 17 & 0 & 1 & 1 & 1 \\
\hline & Orchard soil & Apr & Almond seedlings & 3 & 0 & 3 & 0 & 0 \\
\hline & Orchard soil & Apr & Pear & 5 & 0 & 1 & 0 & 0 \\
\hline \multirow[t]{3}{*}{3} & Scaffold crotch pocket & Nov & in situ pear & 5 & 0 & 0 & 0 & 0 \\
\hline & Scaffold crotch pocket & Feb & Almond seedlings & 1 & 1 & 0 & 0 & 0 \\
\hline & Orchard soil & Feb & Almond seedlings & 1 & 1 & 0 & 0 & 0 \\
\hline 6 & Scaffold crotch pocket & $\mathrm{Feb}$ & Almond seedlings & 5 & 1 & 0 & 1 & 0 \\
\hline
\end{tabular}

$\mathrm{x}$ The natural depression that forms where the tree trunk and scaffold branches join.

${ }^{y}$ Firm, green pears were placed in scaffold crotch pocket and subjected to flooding for two 10-h periods on 2 successive days. After flooding, pears were incubated at room temperature and observed during 7 days for lesion development. Lesion tissue was cultured in PARP selective medium.

${ }^{\mathrm{z}}$ Volunteer almond seedlings $(12 \mathrm{~cm}$ tall) were collected from sites indicated and cultured on PARP selective medium. 
zations can be made. The aboveground infections seem most likely during cool to moderate temperatures when free moisture is present on aerial tree parts for prolonged periods. These conditions can occur intermittently in fall, winter, and spring in the San Joaquin Valley. We found no clear evidence that direct wetting of almond tree trunks by irrigation water was required for LPC infection (Table 1), but the wetting around root crowns may have contributed to the belowground infections. In soil, prolonged and frequent periods of water saturation and cool to moderate temperatures favor development of Phytophthora crown rot $(3,21,22,33)$. With $P$. cactorum in New York State, seasonal infective activity as detected by a soil/baiting assay was greatest in late spring and early summer (16). In our study, the isolation of $P$. cactorum and $P$. citricola from recently germinated almond seedlings in February, March, and April (Table 4) suggests that the two Phytophthora spp. were infective before or during spring months; due to moisture and chilling requirements for germination, the almond seedlings had probably not sprouted until winter. In previous studies, apple and peach were most susceptible to $P$. cactorum and $P$. citricola, respectively, during the growing season $(5,13)$. Similar effects may influence development of LPC in almond.

Temperature responses of $P$. cactorum and $P$. citricola suit them to infection and colonization of almond trees during warmer periods than those conducive for disease caused by $P$. syringae. At $2^{\circ} \mathrm{C}$, Bostock and Doster found that $P$. syringae induced cankers in almond; whereas $P$. cactorum and $P$. citricola did not (2). At $7^{\circ} \mathrm{C}, P$. syringae caused more rapid canker expansion than did $P$. citricola, and $P$. cactorum caused no disease (2). Canker isolates of $P$. cactorum and $P$. citricola in this study were capable of growth at $28^{\circ} \mathrm{C}$; whereas those of $P$. syringae were not (data not shown).

The seedling and pear assays (Tables 4 and 5) revealed several potential reservoirs of inoculum for P. cactorum and P. citricola. The main inoculum reservoir of these pathogens is probably soil associated, but their presence in the scaffold crotch pockets and trapped harvest debris suggests that aboveground inoculum sources may also play a role in epidemiology of LPC. Most of the aboveground debris collected during harvest was probably deposited from nut sweeping and pickup operations, which rely, in part, upon high-energy blasts of air to move the nuts and separate them from debris. Inoculum in the debris would be exposed to extremes of heat and dryness during harvest, when hot, dry weather predominates. Under these conditions, oospores, which are the most persistent of all propagules produced by Phytophthora (31), may be important for survival. Extended wetness periods and cool to moderate air temperatures that typically favor infection by Phytophthora spp. would usually not occur until weeks or months after harvest.

Diverse sources of inoculum and mechanisms of aboveground dispersal have been demonstrated for many other Phytophthora-induced diseases and conceivably could be important for LPC. For example, $P$. cactorum and $P$. syringae are dispersed to low-hanging apple fruits on rain-splashed soil particles (11). Doster reported that $P$. syringae infected almond leaves on the orchard floor, but the mechanism for dispersal to pruning wounds was unknown (9). Wind and rain splashing can disperse whole (caducous) sporangia of several Phytophthora spp., including $P$. cactorum $(11,31)$. P. citricola, however, which was the most prevalent Phytophthora sp. causing LPC, produces noncaducous sporangia (11). Various pests, including ants, rodents, and snails, can vector some Phytophthora spp. $(10,11)$. Ants and rodents are common pests in California almond orchards. We have not investigated the role of rain, wind, or animal dispersal mechanisms in development of LPC.

Our findings suggest that control strategies for Phytophthora diseases of almond should consider aboveground as well as belowground modes of attack by the pathogens. Early tree training to select scaffold branches that are spaced widely apart on the tree trunk may reduce subsequent incidence of scaffold crotch pockets and LPC cankers there. Losses due to soilborne infections by $P$. cactorum and $P$. citricola may be minimized by choosing a rootstock with relatively high resistance to the pathogens, establishment of the graft union several centimeters above the soil line, and use of careful soil water management. Research is underway on integrated control strategies for LPC.

\section{LITERATURE CITED}

1. Baker, K. F. 1972. The U.C. system for producing healthy container grown plants. Calif. Agric. Exp. Stn. Manual 23:68-85.

2. Bostock, R. M., and Doster, M. A. 1985 Association of Phytophthora syringae with pruning wound cankers of almond trees. Plant Dis. 69:568-571.

3. Browne, G. T., and Mircetich, S. M. 1988. Effects of flood duration on the development of Phytophthora root and crown rots of apple. Phytopathology 78:846-851.

4. Browne, G. T., and Mircetich, S. M. 1995 Phytophthora root and crown rots. Pages 3840 in: Compendium of Stone Fruit Diseases J. M. Ogawa, E. I. Zehr, G. W. Bird, D. F Ritchie, K. Uriu, and J. K. Uyemoto, eds. American Phytopathological Society, St. Paul, MN.

5. Browne, G. T., and Mircetich, S. M. 1996. Effects of month of inoculation on severity of disease caused by Phytophthora spp. in apple root crowns and excised shoots. Phytopathology 86:290-294.

6. Browne, G. T., and Viveros, M. 1998. Diverse symptoms and losses associated with Phytophthora spp. in California almonds. Acta Hortic. 470:570-575.

7. Covey, R. P., Jr., and Harris, D. C. 1990 Phytophthora fruit rot. Pages 30-31 in: Compendium of Apple Diseases. A. L. Jones and H. S. Aldwinckle, eds. American Phytopathological Society, St. Paul, MN.

8. DeVay, J. E., Lukezic, F. L., English, H., Trujillo, E. E., and Moller, W. J. 1968. Ceratocystis canker of deciduous fruit trees. Phytopathology 58:949-956.

9. Doster, M. A., and Bostock, R. M. 1988. Incidence, distribution, and development of pruning wound cankers caused by Phytophthora syringae in almond orchards in California. Phytopathology 78:468-472.

10. El-Hamalawi, Z. A., and Menge, J. A. 1996. The role of snails and ants in transmitting the avocado stem canker pathogen, Phytophthora citricola. J. Am. Soc. Hortic. Sci. 121:973977.

11. Erwin, D. C., and Ribeiro, O. K. 1996. Phytophthora Diseases Worldwide. American Phytopathological Society, St. Paul, MN.

12. Farr, D. F., Bills, G. F., Chamuris, G. P., and Rossman, A. Y. 1989. Fungi on Plants and Plant Products in the United States. American Phytopathological Society. St. Paul, MN.

13. Felix, R. F. 1990. Role of different Phytophthora species in root and crown rot of peach and some factors influencing severity of disease. Ph.D. diss. University of California, Davis.

14. Hartman, H. T., Kester, D. E., Davies, F. T., Jr., and Geneve, R. L. 1997. Plant Propagation, Principles and Practices. 6th ed. Prentice Hall, Upper Saddle River, NJ.

15. Haygood, R. A., Graves, C. H., and Ridings, W. H. 1986. Phytophthora root rot and stem canker of peach trees in Mississippi. Plant Dis. 70:866-868.

16. Horner, I. J., and Wilcox, W. F. 1996. Temporal changes in activity and dormant spore

Table 5. Detection of Phytophthora spp. in debris deposited on trees during normal harvest operations

\begin{tabular}{|c|c|c|c|c|c|c|}
\hline \multirow[b]{2}{*}{ Source of debris ${ }^{x}$} & \multirow[b]{2}{*}{ No. of samples } & \multicolumn{5}{|c|}{ Percent samples yielding Phytophthora spp. to pear baits } \\
\hline & & P. cactorum & P. citricola & P. parasitica & P. syringae & Phytophthora sp. $^{\mathrm{z}}$ \\
\hline None (control) & 58 & 0 & 0 & 0 & 0 & 0 \\
\hline Orchard 1 & 46 & 0 & 19 & 4 & 6 & 9 \\
\hline Orchard 2 & 47 & 2 & 27 & 0 & 13 & 17 \\
\hline
\end{tabular}

${ }^{x}$ Debris was collected in clear plastic tarps that nested within the bases of scaffold branches during 8 to 10 days of normal harvest operations.

y Each sample was baited with a pear fruit in a growth chamber on one to three separate occasions.

${ }^{\text {z }}$ An unidentified Phytophthora sp.; morphologically distinct from $P$. cactorum, $P$. citricola, and $P$. syringae. 
populations of Phytophthora cactorum in New York apple orchard soils. Phytopathology 86:1133-1139.

17. Jeffers, S. N., and Wilcox, W. F. 1990. Phytophthora crown, collar, and root rots. Pages 43-45 in: Compendium of Apple Diseases. A. L. Jones and H. S. Aldwinckle, eds. American Phytopathological Society, St. Paul, MN.

18. Kannwischer, M. E., and Mitchell, D. J. 1978. The influence of a fungicide on the epidemiology of black shank of tobacco. Phytopathology 68:1760-1765.

19. Kouyeas, H. 1971. On the apoplexy of stone fruit trees caused by Phytophthora spp. Annls. Inst. Phytopathol. Benaki, N. S. 10:163-170.

20. Maas, J. L., Ed. 1992. Compendium of Strawberry Diseases. American Phytopathological Society, St. Paul, MN.

21. Matheron, M. E., and Mircetich, S. M. 1985. Influence of flooding duration on development of Phytophthora root and crown rot of Junglans hindsii and Paradox walnut rootstocks. Phytopathology 75:973-976.

22. Mircetich, S. M., and Browne, G. T. 1987. Phytophthora root and crown rot of deciduous fruit trees: Progress and problems in etiology, epidemiology and control. Pages 64-65 in:
Proc. Summerland Res. Stn. Commem. Symp.: Challenges and Opportunities in Fruit Production, Protection and Utilization Research. N. E. Looney, ed. Summerland, B. C., Canada.

23. Mircetich, S. M., and Browne, G. T. 1988. Use of resistant rootstocks and soil water management for control of Phytophthora root and crown rot of fruit and nut trees. (Abstr.) Proc. Int. Congr. Plant Pathol., 5th, Section IX, 5-3, p. 311

24. Mircetich, S. M., and Keil, H. L. 1970. Phytophthora cinnamomi root rot and stem canker of peach trees. Phytopathology 60:13761382.

25. Mircetich, S. M., Moller, W. J., and Chaney, D. H. 1974. Phytophthora crown rot and trunk canker of almond trees. (Abstr.) Proc. Am. Phytopathol. Soc. 1:58.

26. Ogawa, J. M., and English, H. 1991. Diseases of temperate zone tree fruit and nut crops. University of California, Division of Agriculture and Natural Resources, Oakland. Publ. 3345.

27. Reilly, C. C., Hotchkiss, M. W., and Hendrix, F. F., Jr. 1998. Phytophthora shuck and kernel rot, a new disease of pecan caused by Phytophthora cactorum. Plant Dis. 82:347-349.
28. Teviotdale, B. L., and Harper, D. H. 1991. Infection of pruning and small bark wound in almond by Ceratocystis fimbriata. Plant Dis. 75:1026-1030.

29. Timmer, L. W., and Menge, J. A. 1988. Phy tophthora-induced diseases. Pages 22-24 in: Compendium of Citrus Diseases. J. O. Whiteside, S. M. Garnsey, and L. W. Timmer, eds. American Phytopathological Society, St. Paul, $\mathrm{MN}$.

30. Waterhouse, G. M. 1963. Key to the species of Phytophthora de Bary. In: Commonwealth Mycological Papers, No. 92. Commonwealth Mycological Institute, Kew, Surrey, Eng.

31. Weste, G. 1983. Population dynamics and survival of Phytophthora. Pages 237-257 in Phytophthora: Its Biology, Taxonomy, Ecology, and Pathology. D. C. Erwin, S. BartnickiGarcia, and P. H. Tsao, eds. American Phytopathological Society, St. Paul, MN.

32. Wicks, T., and Lee, T. C. 1986. Phytophthora crown rot of almond trees. Aust. J. Agric. Res. 37:277-287.

33. Wilcox, W. F., and Mircetich, S. M. 1985. Effects of flooding duration on the development of Phytophthora root and crown rots of cherry. Phytopathology 75:1451-1455. 